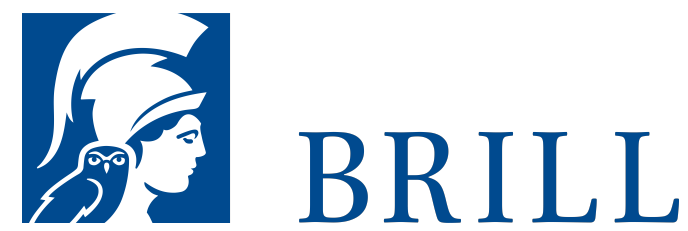

\title{
Erklären und Verstehen fiktionaler Filme
}

Semantische und ontologische Aspekte

Author: Jonas Koch

Warum kürzen die Indianer die lange Verfolgungsjagd in John Fords Stagecoach nicht einfach dadurch ab, dass sie die Zugpferde der Postkutsche erschießen? - 'Weil dann der Film zu Ende gewesen wäre', ist die bestechend einfache Antwort des Regisseurs. Er verweist damit auf die etwas paradox anmutende ontologische Struktur fiktionaler Filme, die zwar als bloße Aufzeichnung eines frei erfundenen Geschehens erscheinen, aber gleichzeitig, und eigentlich primär, eingebettet sind in einen ganz realen kommunikativen Austausch zwischen Filmproduzenten und -rezipienten. Einen Film zu verstehen, bedeutet daher gleichermaßen, die Kausalität des darin dargestellten Geschehens wie auch die kommunikativen Zwecke der Darstellung zu ergründen. Hierzu entwickelt dieses Buch eine umfassende, semantisch und ontologisch fundierte Theorie fiktionaler Erklärungen, aus der sich nicht nur eine systematische Schärfung des erzähltheoretischen Begriffs der Motivierung, sondern letztlich auch eine allgemeine hermeneutische Theorie des Films ableiten lässt. Die Komplexität dieses scheinbar simplen Zusammenhangs zeigt eine abschließende Analyse der raffinierten Irreführungsstrategien von Hitchcocks Psycho.

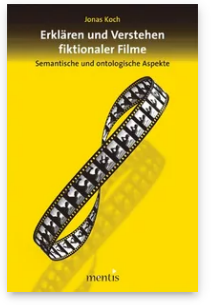

Pages: 241

Seiten

Language:

German

Subjects:

General,

Literature and

Cultural Studies

Publisher: Brill | mentis

E-Book (PDF)

Released online:

19Jan 2015

ISBN: 978-3-

89785-993-7

List price

Paperback

Publication date:

19Jan 2015

ISBN: 978-3-

89785-992-0

List price 
For more information see brill.com

Order information: Order online at brill.com +44330 333 0049 | customerservices@brill.com Submission information: brill.com/authors

Titles published by Brill | Fink, Brill | mentis or Brill | Schöningh: +49(o)715413279216| brill@brocom.de 